\title{
Implementation of Worksheet Moral Dilemma Through Problem Solving of Wetlands
}

\author{
Aminuddin Prahatama Putra, Desica Amalia \\ Biology Education of Universitas Lambung Mangkurat Banjarmasin \\ aminuddinpatra@ulm.ac.id,desicamalia@gmail.com
}

\begin{abstract}
Scientific problems and phenomena in nature can be developed in learning. Creating scientific products that have moral in the educational dimension were solved through problem-solving, including the problem of wetlands. Material of wetlands in biology learning is carried out through teaching moral values through the implementation of worksheet. This research aims to describe the implementation of the moral dilemma worksheet on the concept of the Ecosystem Component through the problem solving of wetlands. This research was a development research using formative evaluation design from Tessmer. The research participants were high school students in Banjarmasin. Data collection was obtained from the assessment of the average $\mathrm{N}$-Gain ability to solve wetland problems, and student responses. The analysis of the effectiveness level of solving wetland problems obtained from post-test scores, and the students' quantitative responses. The results showed that the implementation of Moral Dilemma Worksheet on the $\mathrm{N}$-Gain aspect of understanding the problem was 0.76 ; aspects of problem-solving planning 0.64 ; aspects of solving problems 0.63 ; and the aspect of reassessing the outcome of the problem is $\mathbf{0 . 6 0}$. Student's response to the moral dilemma worksheet moral on the aspects of interest obtained criteria very interested in the value of $64.83 \%$.
\end{abstract}

Keywords-Worksheet, moral, dilemma, solving, wetlands.

\section{INTRODUCTION}

Learning and learning have different but interrelated concepts. Learning defined as a process of behavior change. The changing of behavioral including cognitive, affective, and psychomotor changes. Whereas learning related to reciprocity and communication between students and teachers. During the learning process activities, students are asked to integrate their physical and mental activities to achieve predetermined learning goals so that the learning process can take place actively, innovatively, creatively and fun with the use of learning tools that support the learning atmosphere.

One learning tool that can be used is a student worksheet or often called a student worksheet (LKPD). LKPD is one of the learning resources that can be developed by educators as facilitators in learning activities [1]. LKPD that is prepared can be designed and developed in accordance with the conditions and situations of learning activities that will be faced.

Learning High School Biology listed in the Minister of National Education Regulation No. 22 of 2006 concerning the standard of education content is to develop the ability to think analytically, inductively, and deductively by using concepts and principles of biology. As we all know, the current problem is that the LKPD used by the teacher is not contextual with the environment around the students, both the school environment and the environment of the wetlands around which is associated with student morale.

This land can be in fresh, brackish and salty waters, the process of formation can be natural or artificial. temporary or temporary with landing or flowing water, including the marine area which at the time of receding is not more than six meters [2. To get LKPD that suits your needs, developing a LKPD needs to be combined with a learning model that suits the needs of students.

Model Steps of Learning Problem Solving according to Polya [3], is (a model of problem-solving / problem solving) not just a method of teaching but also a method of thinking, because in problem-solving can use other methods starting with finding data to draw a conclusion. The ability to solve problems related to one's moral consequences, in general, it can be said to vary according to differences in personality, way of thinking, and behavior. At present, moral problems that occur are far more and more complex than moral issues that occur at an early age [4].

Moral development is often harmonized with one's cognitive development. Therefore, to see the process of developing students' morale, problem-solving is needed. The problem that has been chosen is the problem of the wetland environment, especially the environment around students. To create a scientific product that is moral in the educational dimension is solved through problem-solving, including the problem of wetlands. Media by utilizing wetlands in biology learning is carried out through teaching moral values through the implementation of worksheets. This study aims to describe the implementation of the moral dilemma of the worksheet on the concept of the Ecosystem Component by solving the problem of wetlands.

\section{METHOD}

This research is a development research (Research Development). This study used the Formative Evaluation development model of Tessmer [5]. This development research produced a product in the form of a Student Worksheet (LKPD) through a model of solving a morally based wetland problem on the concept of the Ecosystem Component. 


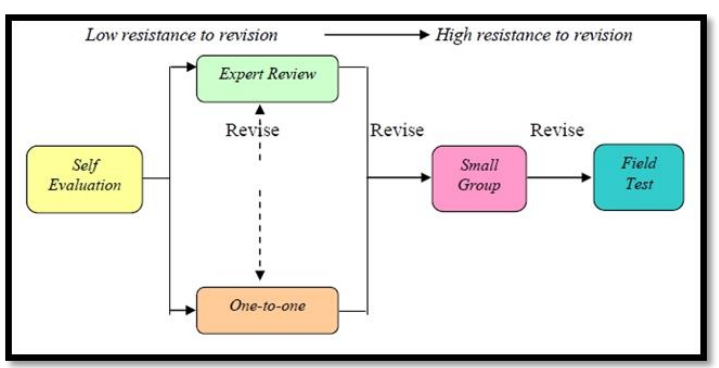

Fig. 1. Formative Evaluation design flow

The participants of this study were high school students in Banjarmasin. Data collection techniques were obtained from the assessment of average ability to solve wetland problems and are supported by student responses. Analysis of the effectiveness level of solving wetland problems from the acquisition of scores for solving problems and quantitative responses of students by averaging them then compared with the adaptation category [6].

TABLE I. Data AsSessment CRiteria For Percentage of Product EFFECTIVENESS.

\begin{tabular}{|l|l|}
\hline \multicolumn{1}{|c|}{ Percentage } & \multicolumn{1}{|c|}{ Criteria } \\
\hline $81 \%-100 \%$ & Very effective \\
\hline $61 \%-80 \%$ & Effactive \\
\hline $41 \%-60 \%$ & Effactive enough \\
\hline $21 \%-40 \%$ & Less effective \\
\hline $0 \%-20 \%$ & Very Ineffactive \\
\hline
\end{tabular}

\section{RESULT AND DISCUSSION}

\section{A. Implementation Data of Student Worksheets}

The Students' Worksheet concept of the Ecosystem Component consists of 3 LKPD with each topic; (1) Components of Ecosystems, (2) Relationship between Components of Ecosystems, (3) Unbalance of Ecosystems. The effectiveness of LKPD is measured through an assessment of average ability to solve wetland's problems and students' responses or opinions. The data obtained in the form of quantitative data and qualitative data. Following are the results of the recapitulation of the LKPD validation of the Concept of Ecosystem Components in Table II.

TABLE II. AVERAGE SUMMARY OF PROBLEM SOLVING ASSESSMENT RESULTS

\begin{tabular}{|c|c|c|c|c|c|c|}
\hline $\begin{array}{l}\text { Problem } \\
\text { solving }\end{array}$ & Group & $\begin{array}{c}\text { LKPD } \\
1(\%)\end{array}$ & $\begin{array}{c}\text { LKPD } \\
2(\%)\end{array}$ & $\begin{array}{c}\text { LKPD } \\
3(\%)\end{array}$ & $\begin{array}{c}\text { Aver } \\
\text { age } \\
(\%)\end{array}$ & $\begin{array}{l}\text { Cate } \\
\text { gory }\end{array}$ \\
\hline \multirow{5}{*}{$\begin{array}{l}\text { Understand } \\
\text { the problem }\end{array}$} & 1 & 80 & 80 & 80 & 80 & \multirow{5}{*}{$\begin{array}{l}\text { Effec } \\
\text { tive }\end{array}$} \\
\hline & 2 & 80 & 80 & 70 & 76 & \\
\hline & 3 & 80 & 80 & 80 & 80 & \\
\hline & 4 & 80 & 80 & 80 & 80 & \\
\hline & 5 & 80 & 80 & 90 & 83 & \\
\hline \multicolumn{5}{|l|}{ Average } & 79.8 & \\
\hline \multirow{4}{*}{$\begin{array}{l}\text { Identify } \\
\text { problem }\end{array}$} & 1 & 80 & 80 & 80 & 80 & \multirow{4}{*}{$\begin{array}{l}\text { Effec } \\
\text { tive }\end{array}$} \\
\hline & 2 & 70 & 70 & 80 & 73 & \\
\hline & 3 & 80 & 80 & 80 & 80 & \\
\hline & 4 & 70 & 80 & 70 & 73 & \\
\hline
\end{tabular}

\begin{tabular}{|c|c|c|c|c|c|c|}
\hline $\begin{array}{c}\text { Problem } \\
\text { solving }\end{array}$ & Group & $\begin{array}{c}\text { LKPD } \\
1(\%)\end{array}$ & $\begin{array}{c}\text { LKPD } \\
2(\%)\end{array}$ & $\begin{array}{c}\text { LKPD } \\
\mathbf{3}(\%)\end{array}$ & $\begin{array}{c}\text { Aver } \\
\text { age } \\
(\%)\end{array}$ & $\begin{array}{l}\text { Cate } \\
\text { gory }\end{array}$ \\
\hline & 5 & 80 & 80 & 80 & 80 & \\
\hline \multicolumn{5}{|l|}{ Average } & 77.2 & \\
\hline \multirow{5}{*}{$\begin{array}{l}\text { Solve } \\
\text { problem }\end{array}$} & 1 & 88 & 84 & 84 & 85 & \multirow{5}{*}{$\begin{array}{l}\text { Very } \\
\text { Effec } \\
\text { tive }\end{array}$} \\
\hline & 2 & 92 & 84 & 84 & 86 & \\
\hline & 3 & 84 & 84 & 96 & 88 & \\
\hline & 4 & 88 & 84 & 88 & 86 & \\
\hline & 5 & 88 & 88 & 88 & 88 & \\
\hline \multicolumn{5}{|l|}{ Average } & 86.6 & \\
\hline \multirow{5}{*}{$\begin{array}{l}\text { Check the } \\
\text { results of } \\
\text { problem } \\
\text { solving } \\
\text { (check } \\
\text { answer) }\end{array}$} & 1 & 80 & 86 & 76 & 81 & \multirow{5}{*}{$\begin{array}{l}\text { Very } \\
\text { Effec } \\
\text { tive }\end{array}$} \\
\hline & 2 & 73 & 83 & 86 & 81 & \\
\hline & 3 & 73 & 83 & 86 & 81 & \\
\hline & 4 & 76 & 80 & 86 & 81 & \\
\hline & 5 & 83 & 80 & 80 & 81 & \\
\hline \multicolumn{5}{|l|}{ Average } & 81 & \multirow{6}{*}{$\begin{array}{l}\text { Very } \\
\text { Effec } \\
\text { tive }\end{array}$} \\
\hline \multirow{5}{*}{$\begin{array}{l}\text { Draw a } \\
\text { conclusion) }\end{array}$} & 1 & 80 & 80 & 80 & 80 & \\
\hline & 2 & 90 & 80 & 80 & 83 & \\
\hline & 3 & 70 & 80 & 80 & 76 & \\
\hline & 4 & 80 & 80 & 90 & 83 & \\
\hline & 5 & 80 & 90 & 90 & 86 & \\
\hline \multicolumn{5}{|l|}{ Average } & 81.6 & \\
\hline
\end{tabular}

Table II showed the average results of student problem solving in groups at LKPD for meeting 1 about the Ecosystem Component, LKPD for meeting 2 is on the Relationship between Components of Ecosystems and LKPD for meeting 3 about Environmental Unbalance (Ecosystem), namely the syntax of understanding the problem of average score data obtained $79.8 \%$, syntax identify problems average score obtained $77.2 \%$, syntax resolves the problem of an average score of $86.6 \%$, syntax checks the results of completion (checking answers) the average score is $81 \%$ and the syntax is interesting conclusion of the average score obtained is $81.6 \%$. Based on Table II, the average score of process skills ranged from $77.2 \%$ to $86.6 \%$ (Categories can be said to be effective at least) for the implementation of LKPD.

\section{B. Implementation of Student Worksheets}

The Student's Worksheet (LKPD) model for solving the moral-based wetland problem in the Ecosystem Component concept developed is classified as effective or well used in the learning process. The implementation of LKPD can be obtained from the results of students 'problem solving using LKPD which is associated with a morally based wetland environment using the Polya problem solving learning model implemented which aims to find out the students' responses during the learning process [7]. 


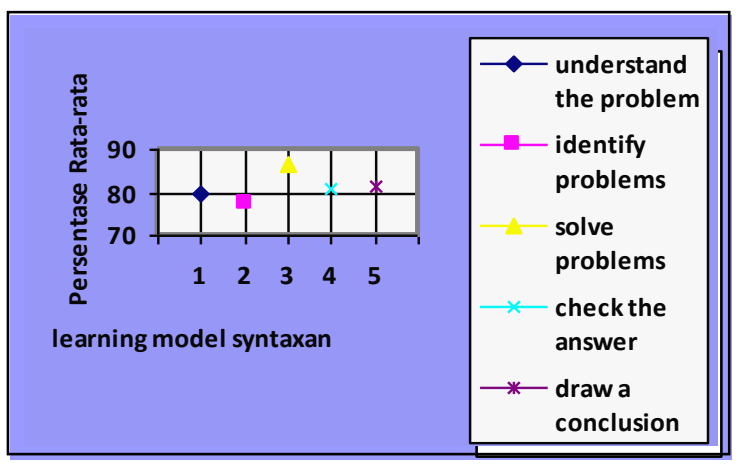

Fig. 2. Average Percentage of results of problem solving seen from LKPD Meetings 1, 2 and 3

LKPD models, the resolution of morally based wetland problems in the concept of Components of Ecosystems developed as effective. The process of solving students' problems is measured by the students' ability to implement each syntax of problem-solving models through the results of students working on LKPD. LKPD development results measured through students' ability to understand problems, identify problems, solve problems, examine the results of the solution (check answers) and draw conclusions.

Based on figure 2 showed the average percentage of the results of the resolution of the problem LKPD for meetings 1,2 and 3 which are associated with a morally based wetland environment with problem solving learning model. In the picture, it can be seen the results of the average assessment of students in understanding the problem by $79.8 \%$ with a good category. Whereas in the process of identifying the average problem obtained by $77.2 \%$, then solving the problem is an average of $86.6 \%$, checking the results of the settlement (checking answers) the average is $81 \%$ and drawing the average conclusion obtained is $81,6 \%$. So, the average outcome of problem solving ranged from $77.2 \%$ to $86.6 \%$ (The minimum category to be classified effective) for the implementation of LKPD.

LKPD development results are declared effective to be used in learning because it has several advantages, such as the use of problem-solving models associated with wetlands and morals, each syntax of problem-solving models carried out by students who will practice the process skills. Zaini and Asnida report that the effectiveness of learning instruments fulfilled is based on: a) cognitive learning outcomes that have been completed, b) results of assessment of critical thinking skills, behavioral characteristics, and social skills, which have achieved good categories, e) student activity in learning process that has been seen [8].

The processing skills to support students' abilities in finding concepts. As explained by Dimyati and Mudjiono that the interaction between process skills with facts, concepts and principles will develop students' attitudes and values [9]. In the problem-solving process is related to the circumstances of the environment and student morale. Students are required to understand each learning model syntax used. The following problem-solving process is in accordance with the learning model syntax used.

\section{1) Understand the problem}

In the first model problem solving syntax is understanding the problem, in this step students understand the problem by writing down what is known and what is asked of the discourse on the LKPD. Based on the discourse contained in LKPD students faced problems related to students' moral attitude in dealing with the surrounding environment and understanding the problems that occur from the discourse that has been provided in LKPD. The average student assessment in understanding the problem is $79.8 \%$. This proves that LKPD is effectively developed in accordance with the category [6].

Practical means it is easy to use by users and can be given and used by all students [5]. As stated by Sudarman that students understand the problem if students are able to express known and asked data from a given problem [10].

\section{2) Identify problems}

The second step of the problem-solving model according to the pattern is Identifying the problem (drawing up a plan). In this step students develop strategies and actions to be taken on the problem given based on understanding the problems they find in the first syntax. As stated by Sudarman that a number of strategies can help to formulate a problem-solving plan [10]. In this step students show the average score in identifying problems that is $77.2 \%$, this proved that LKPD is developed using an effective problem-solving model in accordance with the category [6].

\section{3) Solve the problem}

In this step students carry out a problem-solving plan that has been prepared to solve the given problem and check each step. In the problem-solving plan students will be motivated in the process of thinking how to solve / resolve problems and what actions must be done in solving this problem related to student morale. In line with Sarbaini, the moral value of conflict on the task performed by students will encourage the thinking process, stimulate changes in the development of the child's cognitive structure towards the position and problem solving that will be done [11].

In this step the average percentage obtained was $86.6 \%$, this shows that the LKPD developed using the problem-solving model is very effective in accordance with Akbar's category [6]. It can be said effective as students can solve problems properly. In line with Sari the developed LKPD gets a positive response from students because it meets the criteria, needs and what students want, so LKPD can be used as an alternative that can help students understand the lesson [12].

\section{4) Checking the results of problem solving (checking} answers)

Check the answers obtained. In this step students reexamine the results that have been done so that students can develop their attitudes and scientific values on themselves. As stated by Sudarman that thinking or reviewing the steps that have been done is a very important activity to improve students' ability in problem solving [10]. In this step the average percentage obtained was $81 \%$, this shows that the LKPD developed using the problem-solving model is very effective in accordance with Akbar's category [6]. 


\section{5) Draw conclusions}

In the final step, students draw conclusions from the results of the problem solving. In this step the percentage of the achieving was an average of $81.6 \%$, this showed that the LKPD developed using the problem-solving model is very effective in accordance with Akbar's category [6].

Process skills are similar as thinking skills [13]. When a learner or instructor uses the product and can be used in its entirety, each goal can be sorted into a number of specific questions of general purpose known as effectiveness [14].

\section{CONCLUSION}

Based on the results of the research and discussion, it concluded that the implementation of the effectiveness of LKPD results from the development using a model of moralbased wetland problem solving on the concept of the SMA Ecosystem Component are effective. As showed the average percentage of problem-solving results of $77.2-86.6 \%$ so it means that it is effective.

\section{SUGGestion}

This development research focuses only on LKPD, it is better to develop other learning tools. In this development research only discusses the implementation of LKPD only and focusing on one concept of learning, it is better to conduct LKPD development research on other biological concepts.

\section{REFERENCES}

[1] E. Widjajanti, Kualitas lembar kerja siswa, Pendidikan Kimia FMIPA UNY, 2008.

[2] P. Dugan, and P. J. Dugan, Wetland conservation: A review of current issues and required action, IUCN, 1990.

[3] P. Polya, Model problem solving dalam pembelajaran, Jakarta: Pustaka Buku, 2002.

[4] C. A. Budiningsih, Pembelajaran moral berpijak pada karakteristik siswa dan budayanya, Jakarta: PT. Rineka Cipta, 2008.

[5] M. Tessmer, Planning and conducting formative evaluations, Philadelphia: Kogan Page, 1998.

[6] S. Akbar, Instrumen Perangkat Pembelajaran, Bandung: PT Remaja Rosdakarya. 2013.

[7] Hidayat, T. Pengaruh penggunaan LKS berbasis problem solving polya materi fluida dinamis terhadap kemampuan menganalisis peserta didik, Universitas Islam Negeri Syarif Hidayatullah, 2014.

[8] M. Zaini, and D. J. Asnida, "Pengembangan perangkat pembelajaran IPA- Biologi berorientasi hutan mangrove untuk siswa SMP," Seminar Nasional XII pendidikan Biologi FKIP UNS, 2015.

[9] D. Dimyati and M. Mudjiono, Belajar dan Pembelajaran, Rineka Cipta:Jakarta, 2013

[10] S. Sudarman, Proses berpikir siswa SMP Berdasarkan adversity quotient (AQ) dalam menyelesaikan masalah matematika, Surabaya: Universitas Negeri Surabaya, 2010.

[11] S. Sarbaini. Model pembelajaran berbasis kognitif moral (dari teori ke aplikasi), Universitas Lambung Mangkurat Laboratorium PPKn, 2011.

[12] K. A. Sari, and R. Renny, Pengembangan Lembar Kerja Siswa (LKS) biologi berbasis gambar pada materi sistem pencernaan untuk SMA, Program Studi Pendidikan Biologi STKIP PGRI Sumbar, Jurusan Biologi Universitas Negeri Padang, 2013.

[13] M. Nur, Pembelajaran berpusat pada siswa dan pendekatan konstruktivis dalam pengajaran, Unesa Press: Surabaya, 2000.

[14] M. Tessmer, Planning and conducting - Formative Evaluations, London: Kogan Page, 1993. 